
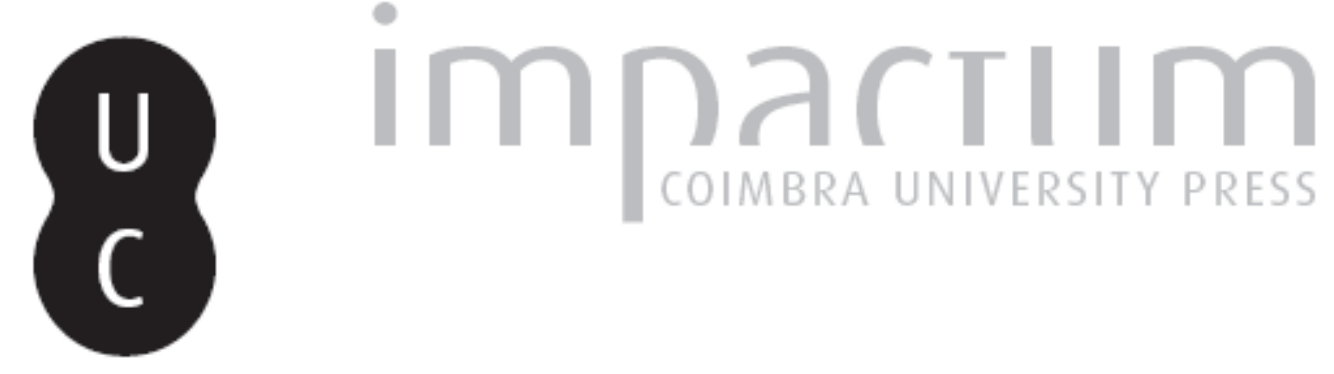

\title{
Montesquieu e a releitura da separação de poderes no Estado contemporâneo: elementos para uma abordagem crítica
}

Autor(es): $\quad$ Carvalho, Alexandre Douglas Zaidan de

Publicado por: Universidade Católica de Petrópolis

URL persistente:

URI:http://hdl.handle.net/10316.2/33874

DOI:

DOI:http://dx.doi.org/10.14195/2175-0947_1-2_2

Accessed : $\quad$ 26-Apr-2023 16:00:59

A navegação consulta e descarregamento dos títulos inseridos nas Bibliotecas Digitais UC Digitalis, UC Pombalina e UC Impactum, pressupõem a aceitação plena e sem reservas dos Termos e Condições de Uso destas Bibliotecas Digitais, disponíveis em https://digitalis.uc.pt/pt-pt/termos.

Conforme exposto nos referidos Termos e Condições de Uso, o descarregamento de títulos de acesso restrito requer uma licença válida de autorização devendo o utilizador aceder ao(s) documento(s) a partir de um endereço de IP da instituição detentora da supramencionada licença.

Ao utilizador é apenas permitido o descarregamento para uso pessoal, pelo que o emprego do(s) título(s) descarregado(s) para outro fim, designadamente comercial, carece de autorização do respetivo autor ou editor da obra.

Na medida em que todas as obras da UC Digitalis se encontram protegidas pelo Código do Direito de Autor e Direitos Conexos e demais legislação aplicável, toda a cópia, parcial ou total, deste documento, nos casos em que é legalmente admitida, deverá conter ou fazer-se acompanhar por este aviso.

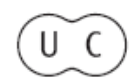



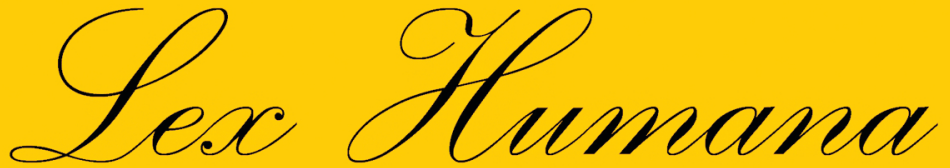

Revista do Programa de Pós-Graduação em Direito da UCP

ISSN(e) 2175-0947

Universidade Católica de Petrópolis Rua Benjamin Constant, 213 - Petrópolis - Centro CEP 25610-130

Tel: (24) 2244-4000 E-mail: lexhumana@ucp.br 


\section{MONTESQUiEU E A RELEITURA DA SEPARAÇÃO \\ DE PODERES NO ESTADO CONTEMPORÂNEO: \\ ELEMENTOS PARA UMA ABORDAGEM CRÍTICA}

Alexandre Douglas Zaidan de Carvalho ${ }^{1}$

RESUMO: O trabalho tem como escopo investigar como se formou a clássica teoria da separação dos poderes, desde suas raízes no pensamento político desenvolvido na Antiguidade por Aristóteles, passando pela formulação da idéia de tripartição das funções de poder do Estado em Montesquieu, de acordo com contextualização histórica no Iluminismo francês, até sua consolidação como princípio jurídico adotado nas constituições modernas como a francesa e a americana, e como as constituições contemporâneas têm trabalhado a idéia de divisão do poder, para ao final formar um prognóstico crítico acerca da debatida crise político-institucional no Brasil e os seus reflexos no fenômeno denominado judicialização da política.

Palavras-chave: Montesquieu, separação de poderes, estado contemporâneo.

ABSTRACT: This work aims at studying how the classic theory of the separation of powers was created, tracing its roots found in the political thought developed by Aristoteles until the formulation of the idea of the tripartite functions of power systematized by Montesquieu, in accordance to the historical context inspired by the French Enlightenment. The theory has become a law principle adopted by modern Constitutions such as the French and the American. The text also investigates how the contemporary Constitutions have been dealing with the division of powers with the objective of having a critical outlook concerning the debate about the political and institutional crisis in Brazil and its effects on the so called phenomenon of judicialization of politics.

Keywords: Montesquieu, separation of powers, contemporary state.

1 Alexandre Douglas Zaidan de Carvalho é Procurador Federal-AGU em exercício na Procuradoria Regional Federal da $5^{\mathrm{a}}$ Região-Recife/PE, especialista em Direito Público pelo Instituto Brasiliense de Direito Público/IDP, mestrando em Direito Público pela UFPE e professor de direito constitucional da Universidade Salgado de Oliveira. 


\section{Introdução.}

Propõe-se com o presente artigo levantar informações e considerações sobre como a clássica doutrina política da divisão de poderes, geralmente atribuída ao filósofo político francês Charles de Montesquieu, tem sido tratada nos textos constitucionais, em especial o da Constituição da República Federativa do Brasil de 1988, objetivando analisar aspectos relacionados à tão propagada crise institucional das funções de poder do Estado e algumas das alternativas propostas para sua superação.

$\mathrm{Na}$ busca de uma análise do pensamento construído sobre as bases da doutrina da separação de poderes e buscando tratar dos reflexos proporcionados por tal perspectiva na prática constitucional observada na construção dos Estados Democráticos de Direito, dirigir-se-á o artigo, em um primeiro momento, a contextualizar o tempo histórico em que a doutrina da separação de poderes tomou importância na teoria política.

Tratado o tema sob esse prisma, após o delineamento devidamente esclarecido do que consiste a proposta de uma tripartição dos poderes no paradigma clássico, erigido sob a influência do pensamento iluminista, a que o historiador Reinhart Koselleck consigna suas críticas, úteis a presente análise, dirigir-se-á a intenção deste trabalho em avaliar como essas idéias foram absorvidas e transformadas no relacionamento entre os poderes e como essas transformações acabaram por gerar a crise político-institucional, cuja própria existência é questionada entre os que se dedicam ao tema.

Formado um breve prognóstico sobre a forma e conseqüências da absorção da doutrina da separação de poderes na realidade constitucional brasileira, o artigo examinará como o desenvolvimento de atividades típicas de uma das funções de Poder do Estado têm sido sistematicamente transferidas para outra(s) esfera(s) de decisão, muitas vezes sem que a própria sociedade perceba e reflita sobre tal fator de possível desequilíbrio institucional.

\section{As origens e o contexto da doutrina da separação de poderes.}

É comum atribuir-se a autoria e primeira referência à teoria da separação de poderes à Montesquieu, olvidando-se, em geral, do alerta para a necessidade de divisão de funções do governo da Pólis grega, feita na filosofia clássica de Aristóteles em Politikón, escrito no século III a. C, obra em que o filósofo grego fez uma ampla análise da sociedade helênica 
e suas instituições, leis, constituições, formas de governo, oportunidade em que inclusive chegou a denominar o homem animal político.

Pois bem, para Aristóteles, independentemente da forma de governo que a Cidade adotasse, a sua constituição como instrumento de liberdade e poder, deveria ostentar condições e qualidades convenientes ao povo a que se destinasse.

Uma das qualidades das constituições referenciadas por Aristóteles é a distribuição dos elementos que compõem o poder soberano da Cidade, como se pode observar na seguinte passagem:

Toda Cidade tem três elementos, cabendo ao bom legislador examinar o que é mais conveniente para cada constituição. Quando essas partes forem bem ordenadas, a constituição será bem ordenada, e conforme diferem umas das outras, as constituições também diferem. A primeira dessas partes concerne à deliberação sobre os assuntos públicos; a segunda, às magistraturas: qual deve ser instituída, qual deve ter sua autoridade específica e como os magistrados devem ser escolhidos; por último, relaciona-se a como deve ser o poder judiciário. ${ }^{2}$

Desse modo, mesmo admitidas as reservas e questionamentos acerca do contexto em que aquela clássica obra foi idealizada, tendo como pano de fundo o cenário grego e suas particularidades, na hierarquizada forma de organização social, entre homens livres, mulheres, estrangeiros e escravos, além do relacionamento existente entre as Cidades e até mesmo a forma de deliberação dos temas atinentes ao interesses dos cidadãos gregos, cujo ambiente muito pouco se assemelha ao vivido por Montesquieu quando da elaboração de $O$ espírito das leis, no século XVIII, e ainda menos ao dos dias atuais, sobre os quais se inclinará a análise feita nesse trabalho, entende-se como indispensável a indicação da antiguidade clássica como embrião da doutrina da divisão de poderes no seio da organização política.

Sob esse prisma, consideradas as distinções dos contextos históricos em que as obras mencionadas foram escritas, característica levada em consideração para que não se caia no risco das comparações anacrônicas,

2 ARISTÓTELES. Política. $5^{\text {a }}$ edição, trad. Pedro Constantin Tolens. São Paulo: Martin Claret, 2001. p. 170. 
uma semelhança de caráter geral é digna de nota, qual seja a aparente preocupação em dividir atribuições típicas do exercício do poder político.

A lição dos antigos gregos sobre a forma de organização política como uma das grandes contribuições que a filosofia helênica legou aos estudos de Ciência Política no ocidente, justifica, por si só, a proposta de Aristóteles para a separação de poderes, como ressaltado por Ives Gandra da Silva Martins referindo-se ao Direito e à Filosofia na antiguidade:

$\mathrm{O}$ que Locke e a Inglaterra ofertaram para o aprofundamento temático de Montesquieu foi a tripartição equilibrada do poder. Hoje, estamos convencidos - quanto mais lemos os autores modernos - de que, em matéria de Direito, pouco se acrescentou ao que os romanos criaram; e, em matéria de Filosofia, pouco se acrescentou ao que os gregos desvendaram. Qualquer filósofo posterior, como Políbio, que era também historiador, passando por Hume, Hobbes, Locke, Bacon, Maquiavel historiador, filósofo, político e sociólogo - Russeau e outros, traz pequena contribuição ao pensamento universal descortinado pelos gregos. Tenho a impressão de que depois dos gregos pouca coisa se pôde criar. Criaram-se variações inteligentes, mas o tema central de Filosofia se encontra na Grécia e do Direito em Roma. Ora, com a tripartição equilibrada de poderes e Montesquieu, chega-se à discussão do sistema de governo, já a esta altura, após a Revolução Francesa, eliminando-se de vez a possibilidade de se discutir a permanência de monarquias absolutas. ${ }^{3}$

No que concerne ao ambiente em que o Barão de Montesquieu escreveu sua obra, em meados do século XVIII, período pré-revolucionário na França medieval de até então, especialmente no que tange ao feudal modo de produção e o conservador modelo hierarquizado de relações sociais, onde o clero, a nobreza e o povo, eram governados por uma monarquia absolutista 
em que a vontade do Rei era soberana e confundia-se com a vontade do próprio Estado, pode-se considerar que a proposta de separação de poderes, ainda que não original, foi, ao seu modo, inovadora.

Mas se é possível estabelecer uma semelhança entre a proposta de Aristóteles, formulada com base na análise de 158 constituições do mundo helênico, de que os governos das Cidades melhor estariam se organizassem o exercício do poder através de funções separadas, e a de Montesquieu em "O espírito das leis", na sua interpretação mais difundida, uma distinção parece merecer registro: a forma de relacionar ética e política.

Aristóteles pode ser considerado o primeiro filósofo a distinguir ética e política, concentrando na primeira o papel desempenhado de forma voluntária, como expressão moral do indivíduo, concebeu a política como o ambiente em que este mesmo indivíduo se relaciona na sociedade, sendo desta indissociável, assim, o homem não pode ser entendido senão como animal político.

Tomando por base esse entendimento, pode-se vislumbrar que ética e política no pensamento aristotélico andavam muito próximas, condição que favorece, portanto, o desenvolvimento de um espaço público propício à construção de relações político-sociais orientadas ao bem-comum e ao interesse de todos, ainda que o espaço de deliberação ficasse restrito aos poucos "cidadãos" gregos.

É de notar-se então no entendimento preconizado pelo filósofo grego, uma clara distinção entre os espaços público e privado, como ambientes bem delineados e relações propriamente definidas, de maneira a evitar que as preocupações e aborrecimentos havidos entre o homem "cidadão" e sua esposa, filhos ou escravos pudesse, de qualquer modo, tomar-lhe o tempo e a atenção necessárias ao bom desempenho da atividade de deliberação dos temas públicos relevantes para a vida da pólis.

Aparte a descrição e minuciosa análise da sociedade helênica feita por Aristóteles, necessária ao aprofundamento do estudo daquela sociedade, é possível afirmar que ele formulou uma teoria de base normativa para a organização política na Grécia antiga, e, reconhecendo as diferenças existentes entre os povos das inúmeras Cidades-Estado, que se refletiam nos distintos costumes, tratou das diversas formas ideais de governo.

Dentre essas formas, todas baseadas nas premissas de que todos aspiram à felicidade, e de que os homens se associam não apenas para viver, mas para viver bem, caso contrário haveria cidades de animais e escravos, conjectura impossível já que estes não participam da felicidade, Aristóteles 
entendia que a busca dessa felicidade no espaço público formava o sujeito político, tornando-o virtuoso.

Em conseqüência, considerando que a forma de governo escolhida e o seu exercício serão tão bons quanto mais virtuoso for(em) o(s) titular(es) do poder de deliberação, elege Aristóteles a monarquia como a melhor forma de governo, seguida da aristocracia, governo dos melhores, e da democracia, entre as formas puras de governo das Cidades.

Diferentemente ocorre no pensamento iluminista no qual se insere a obra de Montesquieu, filósofo precursor de uma antropologia política que leva em conta a diversidade dos homens e de sua natureza, para, a partir dessa compreensão, descrever como se dá o exercício do poder.

Montesquieu não toma por premissa, assim como os demais autores da tradição liberal, a idéia de que a virtuosidade humana e o comportamento moralmente adequado são indissociáveis condicionantes do desempenho da atividade pública, como parecia crer Aristóteles, mas observa o filósofo francês, com desconfiança o exercício do poder político, distinguindo também, e ao seu modo, ética da política.

Logo, se ambos os filósofos tinham a preocupação em organizar o poder político de maneira a estruturá-lo organicamente, de acordo com as funções típicas do Estado, o primeiro, Aristóteles, fê-lo para que o "viver bem" dos cidadãos gregos encontrassem no espaço público deliberativo o seu ambiente, já para o filósofo iluminista, a elaboração de uma teoria organicista do poder político, que resultou na contribuição da divisão de poderes, teve como objetivo limitar a ação despótica da monarquia absolutista, fazendo com que o poder restasse contido pelo próprio poder.

Em suma, dos fundamentos que levaram Aristóteles e Montesquieu a apresentar uma proposta semelhante, a divisão de poderes, registra-se uma diferença característica marcante no pensamento dos dois autores. Enquanto o primeiro parte de uma visão otimista sobre a natureza e comportamento do homem/cidadão no exercício do munus público, o segundo enxerga com desconfiança e pessimismo o desempenho da atividade política, que seria, por natureza, centralizadora e sujeita a arbitrariedades.

E é sobre essa significativa distinção entre as formas de visualizar o legítimo exercício do poder político, passando pela análise da difícil relação entre ética e política, que se aventa a hipótese da propalada crise da separação de poderes do Estado e de suas conseqüências na atividade político-jurisdicional dos agentes públicos na realidade brasileira. 


\section{O pensamento iluminista e a doutrina da separação de poderes na concepção de Montesquieu.}

Estabelecido o contraponto que consiste em um dos problemas fundamentais a que se inclina essa investigação, interessa observar agora o contexto em que a obra referência em análise "O espírito das leis" e o ideal de divisão de poderes proposto por Montesquieu foram formulados.

Sem esquecer as críticas dirigidas aos historiadores que contextualizam as obras pesquisadas de acordo com a situação econômica e política da época vivenciada por seus autores, sob a afirmação de que suas conclusões apresentam-se mais como resultado daquelas condicionantes do que como grande contribuição original daquele que a escreveu, a análise do ambiente histórico em que o iluminismo teve ascensão, relevante ao estudo do tema, parece indispensável ao exame dos reflexos da obra de Montesquieu até os dias atuais.

Sob esse viés, digna de atenção é a clássica obra Crítica e crise, do historiador alemão Reinhart Koselleck, oferecendo uma leitura criteriosa e aprofundada das transformações ideológicas ocorridas no século XVIII, e revelando os elementos que constituíram a gênese não só de um novo Estado, mas da própria razão de ser da política, da arte, da história e do direito, e que, segundo entende aquele autor, estende seus problemas até hoje, como se verifica na seguinte passagem:

A sociedade burguesa que se desenvolveu no século XVIII entendia-se como um mundo novo: reclamava intelectualmente o mundo inteiro e negava o mundo antigo. Cresceu a partir do espaço político europeu e, na medida em que se desligava dele, desenvolveu uma filosofia do progresso que correspondia a esse processo. $\mathrm{O}$ sujeito desta filosofia era a humanidade inteira que, unificada e pacificada pelo centro europeu, deveria ser conduzida em direção a um futuro melhor. Hoje, seu campo de ação, o globo terrestre, é reivindicado ao mesmo tempo por grandes potências, em nome de filosofias da história análogas. ${ }^{4}$

A partir dessa consideração, utilizando-se da razão dialética que

4 KOSELLECK, Reinhart. Crítica e crise: uma contribuição à patogênese do mundo burguês. Trad. de Luciana Villas-Boas Castelo-Branco. Rio de Janeiro: EDUERJ: Contraponto, 1999. p. 09. 
a História proporciona, é possível situar o pensamento iluminista como a tese político-humanista carregada de uma ética sustentada pela classe de intelectuais e membros de um segmento social em crescimento, a burguesia, cuja idéia opunha-se à antítese do poder absoluto exercido por uma monarquia desgastada, cuja síntese resultou na própria Revolução Francesa.

Motiva aquele historiador a sua crítica ao pensamento iluminista, na forma pela qual o declarado discurso pretensamente apolítico e desinteressado revestiu-se como projeto de poder, construído sob o embuste de convicções morais e filosóficas de um grupo de intelectuais, que por assim o serem, julgavam-se mais capacitados para o exercício daquele poder que tanto criticavam.

Relata Koselleck que, após estar assegurada a unidade do Estado com o afastamento das guerras civis e religiosas, justificadoras da prevalência do pensamento de autores como Hobbes e Maquiavel, de que seria necessário um Estado "Leviatã", para proteger os próprios cidadãos de seus desejos egoístas, além de um indispensável "Príncipe", condutor dos destinos da nação de acordo com as nobres intenções que só o autêntico soberano pode ter, a crítica liberal de cunho provado gerada na organização da sociedade burguesa passa a ganhar espaço.

É como se após garantir a unidade territorial e a tão desejada paz religiosa fosse necessário buscar vez e voz para reivindicações progressistas à luz do próximo interesse: o lucro. E se para isso se torna necessário criticar a instituição estatal que garantiu aquela unidade e paz, não custa trazer ao esclarecimento a concepção privada de uma melhor forma para o exercício do poder público, como afirma Koselleck no seguinte trecho:

$\mathrm{O}$ advento da inteligência burguesa tem como ponto de partida $\mathrm{p}$ foro interior privado ao qual o Estado havia confinado seus súditos. Cada passo para fora é um passo em direção à luz, um ato de esclarecimento. $\mathrm{O}$ Iluminismo triunfa na medida em que expande o foro interior privado ao domínio público. Sem renunciar à sua natureza privada, o domínio público torna-se fórum da sociedade que permeia todo o Estado. Por último, a sociedade baterá à porta dos detentores do poder político para, aí também, exigir publicidade e permissão para entrar. $^{5}$ 
Sobre a justificação filosófica dessa novel configuração do poder político, traça o historiador germânico um paralelo entre as idéias de Hobbes e Locke, explicando como a contribuição deste último serviu ao propósito iluminista de inserir no discurso político a opinião formada no seio do interesse privado, observe-se os seguintes trechos que revelam essa justificação:

Locke submete a relação entre as leis morais e as leis políticas, tal como Hobbes a havia formulado, a uma profunda revisão. Mediante a separação entre lei divina e lei civil, concede novamente um caráter obrigatório às religiões e, ao mesmo tempo, provoca uma ruptura entre o direito natural e o direito político, reunidos por Hobbes a fim de justificar o Estado. (...)

Para Locke, as opiniões dos cidadãos sobre a virtude e o vício não estão confinadas ao domínio das convicções e opiniões privadas: os juízos morais dos cidadãos têm caráter de lei. Desta forma, a moral de convicção, excluída do Estado por Hobbes, é duplamente alargada. (...)

Os cidadãos não se submetem apenas ao poder estatal: juntos formam uma sociedade que desenvolve suas próprias leis morais, que se situam ao lado das leis do Estado. Assim, a moral civil - ainda que, conforme sua natureza, tacitamente e em segredo - entra no espaço público. (...)

A legalidade da lei filosófica não repousa na qualificação do seu conteúdo; funda-se no ato de vontade de que se origina. Não é mais o soberano quem decide, mas os cidadãos. Estes, ao emitirem seu juízo, constituem as leis morais, como os negociantes determinam um valor de mercado. ${ }^{6}$

Apresentada foi então a justificativa para permitir o ingresso da moral privada burguesa na condução da atividade política através da crítica, e é sob o manto dessa convicção moral, fundada na ética protestante em 
busca do lucro e acumulação de recursos necessários à ascensão social, que os espaços público e privado acabam por confundir-se.

Vê-se aqui, diferentemente do que ocorria na polis grega, que a formação da virtuosidade ética do cidadão se dá no foro privado, de acordo com os valores de sua família, costumes, religião, profissão/negócio, corporação/associação; tomando por sua vez dimensão universalizante suficiente para projetar-se como valor que não deveria ficar restrito ao âmbito privado, mas sim adquirir ares de publicidade no discurso do progresso moral da sociedade.

Enquanto na Grécia antiga, como se mencionou, a formação ética do cidadão se dava no espaço público, político por natureza, afastadas as variáveis morais individuais, sujeitas às influências do relacionamento do cidadão com sua família, filhos, escravos, propriedades ou comércio; pelo que só assim o zoon politikon poderia constituir-se e agir com a esperada isenção, a formação do sujeito político do Estado moderno partiu da individualidade para construir o chamado "eu coletivo", diferença que pode revelar onde está a origem de muitos dos problemas hoje discutidos na gestão da coisa pública.

A inexorável aproximação entre espaço público e privado, promovida com a crítica iluminista ao Estado absolutista, sob os mais nobres argumentos de respeito às liberdades individuais e à expressão livre do pensamento, direitos fundamentais de primeira geração, ter promovido a hoje criticada utilização do espaço público como privado. É o que se pode compreender da extensão do domínio privado aos mais amplos acessos permitidos pelos espaços públicos, como escreve Koselleck:

Cada ato de julgar dos cidadãos, a distinção que fazem entre o que deve ser considerado como bem ou mal, tornase legal pela própria distinção. As opiniões provadas dos cidadãos são elevadas a leis em virtude de sua censura imanente. Por esta razão, Locke também chama a lei da opinião pública de Law of Private Censure [Lei da censura privada]. Espaço privado e espaço público não são de modo algum excludentes. Ao contrário, o espaço público emana do espaço privado. A certeza que o foro interior moral tem de si mesmo reside em sua capacidade de se tornar público. O espaço privado alarga-se por força própria em espaço público, e é somente no espaço público que as opiniões privadas se manifestam como 


\section{lei. ${ }^{7}$}

Tem-se com isso que o terreno onde fora preparada a forma de organização política vigente após a Revolução Francesa, para Koselleck, está repleto de acontecimentos marcados pela participação de intelectuais, muitas vezes anônimos, e da franco-maçonaria, com seu relevante papel no encorajamento das forças propulsoras da Revolução. Sobre essa brusca transformação do Estado levada a efeito com aquele movimento revolucionário, afirma o historiador:

O Estado moderno estabeleceu-se em duas fases distintas e em virtude de soluções espacialmente distintas para as lutas religiosas. Sua política foi o tema do século XVII, e seus caminhos traçam a história do Absolutismo. O período seguinte, embora se caracterize pelo mesmo poder estatal, recebeu outro nome: Iluminismo. O movimento iluminista desenvolveu-se a partir do Absolutismo, no início como sua conseqüência interna, em seguida como sua contraparte dialética e como o inimigo que preparou sua decadência. ${ }^{8}$

Foi justamente nesse contexto histórico-filosófico que foi desenvolvida a tese de separação de poderes de Montesquieu, cuja interpretação racionalista mais difundida pregou a rígida separação de poderes, como garantia ao respeito dos direitos fundamentais e restrição à utilização arbitrária das funções de poder pelos seus titulares.

\section{Adoutrina da separação de poderes na formação do constitucionalismo moderno e contemporâneo.}

Herdeiro doutrina da tradicional teoria racionalista da divisão de poderes, o constitucionalismo pós-revolucionário elevou aquela doutrina a cânone indispensável das constituições modernas, em que pese a existência de críticas ao racionalismo da rígida separação de poderes e a possibilidade de outras interpretações.

Essa vertente do pensamento racionalista-liberal acabou então 
por projetar-se para o futuro, ganhando força no desenvolvimento das organizações político-constitucionais do Ocidente, e consolidando-se como condição para o exercício legítimo do poder nas democracias modernas, esquecendo as lições da antiguidade clássica sobre a organização do Estado, pois, conforme afirma Koselleck ${ }^{9}$ : “...o iluminista conseqüente não tolerava qualquer inclinação para o passado. O objetivo declarado da Enciclopédia era reelaborar o passado o mais rapidamente possível, de forma que um novo futuro fosse inaugurado.

Pode-se afirmar então que foi nesse contexto que a Declaração de Direitos do Bom Povo da Virgínia, de 1776, considerada a primeira constituição escrita, a Constituição norte-americana de 1787 e a Constituição francesa de 1793, ícones do constitucionalismo moderno clássico, nasceram sob a inspiração de tal ideário, adotando entre seus preceitos a separação de poderes, que nesse momento não constituía apenas doutrina política, mas ganhava o status de princípio jurídico.

Registre-se, no entanto, que a incorporação norte-americana da doutrina da separação de poderes conferiu a esta alguns temperamentos, como a noção de checks and balances, decorrente da diferenciada compreensão dos federalistas sobre a divisão de poderes no governo inglês, chegando à conclusão de que a melhor aplicação da doutrina da divisão teria como qualidade a limitação do poder do parlamento.

Admitida a pertinente observação do professor lusitano José Joaquim Gomes Canotilho, de que mesmo na modernidade, não se mostra adequado falar de apenas um constitucionalismo, consideradas as experiências inglesa, americana e francesa, pelo que aquele doutrinador prefere a expressão "movimentos constitucionais" 10 , o tema é tratado aqui sob a consideração de que o constitucionalismo moderno é todo aquele ligado ao liberalismo político e econômico, próprios do contexto histórico vivenciado após a Revolução Francesa.

E foi sob os renovados ares daquela revolução iluminista burguesa, que soube muito bem fazer-se a forma de pensar mais adequada a todos os povos, através do conhecimento gramático de seus filósofos e historiadores,

9 KOSELLECK, Reinhart. Futuro passado: contribuição à semântica dos tempos históricos. Trad: Wilma Patrícia Maas, Carlos Alberto Pereira - Rio de Janeiro: Contraponto: Ed. PUC-Rio, 2006. p. 56. 
juristas, etc., todos prontos para relevar "a luz, a verdade e a vida", que a Constituição francesa de 1793, em seu preâmbulo, reafirmou os princípios gerais ditados na "Declaração Universal dos Direitos do Homem e do Cidadão" de 1789, dispondo o seguinte:

$\mathrm{O}$ povo francês, convencido de que o esquecimento e o desprezo dos direitos naturais do homem são as causas das desgraças do mundo, resolveu expor, numa declaração solene, esses direitos sagrados e inalienáveis, a fim de que todos os cidadãos, podendo comparar sem cessar os atos do governo com a finalidade de toda a instituição social, nunca se deixem oprimir ou aviltar pela tirania; a fim de que o povo tenha sempre perante os olhos as bases da sua liberdade e da sua felicidade, o magistrado a regra dos seus deveres, o legislador o objeto da sua missão. Por conseqüência, proclama, na presença do Ser Supremo, a seguinte declaração dos direitos do homem e do cidadão. ${ }^{11}$

A adoção dessa vertente universal e racionalista da doutrina iluminista, que ainda não abandonara por completo a crença e a fé em um "Ser Supremo", foi a principal força motriz da elaboração das constituições modernas sob o modelo de democracia liberal que se pretendia instalar, cuja idéia de separação de poderes acabou por privilegiar uma supremacia do legislador, a pretexto de sua maior legitimação popular, como afirma Nelson Juliano Cardoso Matos ao tratar das diversas concepções da separação de poderes no Estado moderno:

Como instrumento democrático, a supremacia do legislativo na doutrina racionalista significa a supremacia do órgão popular. Mas como instrumento contra o arbítrio, pretende limitar o poder (desconcentrando-o e controlando-o). E como princípio jurídico, fundamenta, sobretudo, a retórica das decisões judiciais, principalmente com a postura auto-restritiva, para os juízes não se imiscuírem nas questões dos outros poderes, mas também com a interferência em um poder, com a justificativa de proteger o terceiro poder de uma interferência indevida. ${ }^{12}$

11 MORAES, Alexandre de. Direitos humanos fundamentais. 2. ed. São Paulo: Atlas, v. 3, 1998, p. 24. 
Vê-se, portanto, que mesmo tendo se saído vencedora, e talvez por isso mesmo, o segmento racionalista-liberal de compreensão da teoria da tripartição dos poderes não escapou às críticas, algumas delas consistentes, como a feita por Óscar Godoy Arcaya:

La teoría de la separación de poderes ha sido interpretada de distintos modos. Una de las versiones más radicales sostiene que Montesquieu atribuye las tres funciones esenciales del Estado a órganos — conformados por autoridades individuales o colegiadas - completamente distintos e independientes entre sí. Esas funciones, en consecuencia, estarían completamente separadas. Y esta radical separación sería funcional, personal y material: cada órgano ejercería la totalidad de una función legislativa, ejecutiva o judicial - en forma plenamente independiente y monopólica; ninguna autoridad podría revocar las decisiones de las otras; y a todas les estaria prohibida cualquier relación o comunicación entre ellas. Sin embargo, esa interpretación extrema, además de inaplicable a la realidad, no parece desprenderse de los textos de Montesquieu. Pues, si analizamos el famoso capítulo sexto del libro XI, que trata acerca de la monarquía inglesa, nos encontramos con un cuadro diferente.

Un punto crucial de la argumentación de Montesquieu es que la separación de poderes no es total o absoluta, sino relativa. $^{13}$

Importa, entretanto, constatar a hipótese de que, diante da visão do autor de $O$ espírito das leis sobre a natureza humana e o exercício do poder, revelada nas Cartas Persas, influenciada por Hobbes ${ }^{14}$, a separação de

paradigmática no direito (o caso da judicialização da política no Brasil). Tese de Doutourado - Centro de Ciências Jurídicas / Faculdade de Direito do Recife, Universidade Federal de Pernambuco, Recife. 2007. p. 159.

13 ARCAYA, Oscar Godoy. Antología Política de Montesquieu. Revista Estudios Públicos, otoño, 1996. p. 345.

14 "La argumentación de Montesquieu, a partir de la premisa ultraindividualista, nos demuestra cómo los individuos movidos por un egoísmo radical destruyen las bases de su propia sobrevivencia. Claramente, este escenario tiene un destinatario: Hobbes. Pues se trata bien de mostrarnos que las grandes pasiones del egoísmo y la codicia solamente pueden destruir y no construir." In: ARCAYA, Oscar Godoy. 
poderes proposta visava não a efetiva guarda dos direitos dos cidadãos, mas a preocupação de que o titular do poder, egoísta e arbitrário por natureza, tivesse o exercício de suas funções contido pelo próprio poder.

Inspirado no modelo inglês de separação de poderes, Montesquieu concentrou sua atenção no clássico debate existente na Ciência Política sobre a relação entre a liberdade e o poder, analisando como essa relação se dá nas formas de governo monárquica, despótica e republicana.

Porém, considerando que o contexto sócio-cultural vigente quando da formulação das idéias expostas em $O$ espírito das leis tinha como conceito de liberdade política um conteúdo bem distinto dos dias atuais, de modo que o objetivo traçado para garantir aquela liberdade era a limitar o poder do Estado, sempre fundado numa desconfiança em relação àquele que exerce o poder, seja qual for o regime.

Nota-se, por esse ângulo, que a preocupação fundamental de Montesquieu era a liberdade derivada da contenção do abuso de poder e não a liberdade destinada a garantir ao homem o seu desenvolvimento ético pleno, tendo, por hipótese, que fosse possível dividir as duas faces de uma mesma moeda. É o que parece ficar evidenciado na seguinte passagem:

Quando na mesma pessoa ou no mesmo corpo de magistratura o poder legislativo está reunido ao poder executivo, não existe liberdade, pois pode temer-se que o mesmo monarca ou o mesmo senado apenas estabeleçam leis tirânicas para executá-las tiranicamente.(...) Não haverá também liberdade se o poder de julgar não estiver separado do poder legislativo e executivo. Se estivesse ligado ao poder legislativo, o poder sobre a vida e a liberdade dos cidadãos seria arbitrário, pois o juiz seria o legislador. Se estivesse ligado ao executivo, o juiz poderia ter a força de um opressor. ${ }^{15}$

O problema da liberdade no pensamento político de Montesquieu ganha contornos mais relevantes do que a forma pela qual o cidadão livre teria acesso aos meios necessários ao usufruto dessa mesma liberdade, é o que se pode inferir da seguinte passagem retirada dos capítulos III e IV, do livro décimo segundo, de $O$ espírito das leis:

Antología Política de Montesquieu. Revista Estudios Públicos, otoño, 1996. p. 344. 
É verdade que nas democracias o povo parece fazer o que quer; mas a liberdade política não consiste em se fazer o que se quer. Em um Estado, isto é, numa sociedade onde existem leis, a liberdade só pode consistir em poder fazer o que se deve querer e em não ser forçado a fazer o que não se tem o direito de querer.

Deve-se ter em mente o que é a independência e o que é a liberdade. A liberdade é o direito de fazer tudo o que as leis permitem; e se um cidadão pudesse fazer o que elas proíbem ele já não teria liberdade, porque os outros também teriam este poder.

A democracia e a aristocracia não são Estados livres por natureza. A liberdade política só se encontra nos governos moderados. Mas ela nem sempre existe nos Estados moderados; só existe quando não se abusa do poder; mas trata-se de uma experiência eterna que todo homem que possui poder é levado a dele abusar; ele vai até onde encontra limites. Quem, diria! Até a virtude precisa de limites.

Para que não se possa abusar do poder, é preciso que, pela disposição das coisas, o poder limite o poder. Uma constituição pode ser tal que ninguém seja obrigado a fazer as coisas a que a lei não obriga e a não fazer aquelas que a lei permite. ${ }^{16}$

Se a partir de tais premissas é possível constatar que Montesquieu pretendia dar à liberdade o seu caráter essencial nas relações públicas e de exercício do poder político, não parece restar tão evidente, como intenciona a doutrina racionalista derivada do iluminismo, e incorporada nos textos constitucionais modernos, que aquele autor pregasse uma rígida separação entre os poderes.

Isso porque também se depreende dos escritos de Montesquieu a proposta de um governo moderado, expressão constante em sua obra, que seria capaz de manter-se por suas próprias leis, ao contrário do governo despótico mantido exclusivamente pela força, como descreve o filósofo ao tratar dos princípios deste último governo: 
Um governo moderado pode, tanto quanto quiser, e sem perigo, saltar as rédeas. Mantém-se pelas leis e pela força. Mas, quando, num governo despótico, o príncipe cessa por um momento de erguer o braço; quando não pode destruir imediatamente aqueles que possuem os primeiros lugares, tudo está perdido: pois como o motor do governo, que é o temor, não existe mais, o povo não tem mais protetor. ${ }^{17}$

Ao demonstrar sua opção por uma configuração política que tivesse a previsão de um poder moderador, verdadeiro supervisor da atividade dos demais e salvaguarda da correta divisão de funções entre aqueles, Montesquieu revela sua visão pessoal pessimista sobre os juízes da seguinte maneira:

Dos três poderes de que falamos, o de julgar é, de algum modo, nulo. Restam apenas dois, e como esses poderes, e como esses dois têm necessidade de um poder regulador para moderá-los, a parte do corpo legislativo que é composta de nobres é bastante capaz para esse efeito. (...) Poderia acontecer que a lei, que é ao mesmo tempo clarividente e cega, fosse em certos casos muito rigorosa. Porém, os juízes de uma nação não são, como dissemos, mais que a boca que pronuncia as sentenças da lei, seres inanimados que não podem moderar nem sua força nem seu vigor. ${ }^{18}$

A inestimável contribuição da filosofia política de Montesquieu influenciou inúmeros outros pensadores e estadistas a conduzir seus estudos e formas de governar, abrindo um amplo espectro para a diversidade de entendimentos sobre a sua proposta, característica que parecia prevista pelo próprio filósofo francês, ao arrematar o livro décimo primeiro de sua obra (Das leis que formam a liberdade política em sua relação com a constituição): CAPÍTULO XX

Fim deste livro

Gostaria de pesquisar, em todos os governos moderados que conhecemos, qual é a distribuição dos três poderes e 
através disso calcular os graus de liberdade de que cada um pode gozar. Mas nem sempre se deve esgotar tanto um assunto, que nada se deixe para o leitor fazer. Não se trata de fazer ler, e sim de fazer pensar. ${ }^{19}$

E justamente por isso tem pertinência a afirmação de que os escritos do Barão Charles de Montesquieu, em relação à separação de poderes, assumem conteúdo mais amplo do que a idéia racionalista de divisão rígida entre as diversas funções do Estado, como propõe Nelson Matos:

A obra de Montesquieu, na verdade, é bem mais rica do que a formatação dada pela doutrina racionalista. E deve enorme tributo à doutrina republicana inglesa, bem como à tradição teórica do governo moderado. Mas é claro, não se pode deixar de perceber que Montesquieu é também um liberal e, portanto, o sentido de liberdade que adota é o da independência individual, e como liberal, via no estado o principal inimigo da liberdade. Assim, diferentemente da tradição republicana clássica, a liberdade é realizada na esfera privada livre e não na esfera pública. ${ }^{20}$

As críticas dirigidas à concepção racionalista e liberal da tripartição dos poderes, cuja aplicação restou ainda mais difícil com as mudanças na configuração política e econômica da organização estatal com o advento do Estado Social “como fruto da superação ideológica do antigo liberalismo" 21 , levaram o constitucionalismo contemporâneo a realizar uma releitura da doutrina da separação de poderes.

Não se trata, entretanto, de resgatar a idéia formulada na antiguidade clássica por Aristóteles, mas de compreender que a proposta de Montesquieu abarca também um sentido positivo na atuação política em defesa da liberdade e exercício de direitos pelos cidadãos. E é sobre a efetivação desses direitos que o novo constitucionalismo dirige as suas atenções.

Nesse sentido, amparado nos ensinamentos de Konrad Hesse,

$19 \quad$ Idem, p. 88.

20 MATOS, Nelson Juliano Cardoso. O Dilema da Liberdade: alternativas republicanas à crise paradigmática no direito (o caso da judicialização da política no Brasil). Tese de Doutourado - Centro de Ciências Jurídicas / Faculdade de Direito do Recife, Universidade Federal de Pernambuco, Recife. 2007. p. 162. 
consigna o professor Canotilho:

Aconstitucionalística mais recente salienta que o princípio da separação de poderes transporta duas dimensões complementares: (1) a separação como divisão, controlo e limite do poder - dimensão negativa; (2) a separação como constitucionalização, ordenação e organização do poder do Estado tendente a decisões funcionalmente eficazes e materialmente justas (dimensão positiva).(...)

O princípio da separação na qualidade de princípio positivo assegura uma justa e adequada ordenação das funções do estado e, conseqüentemente, intervém como esquema relacional de competências, tarefas, funções e responsabilidades dos órgãos constitucionais de soberania. Nesta perspectiva, separação ou divisão de poderes significa responsabilidade pelo exercício de um poder. $^{22}$

Canotilho $^{23}$ analisa a importância constitucional da separação de poderes através de três princípios: o jurídico-organizatório (criação de estrutura constitucional com funções, competências e legitimação de órgãos para um comando recíproco do poder - check and balances); o normativo autônomo (possibilidade de "compartimentação" de funções para justificar a justeza de uma decisão), e o princípio fundamentador de incompatibilidades (necessário à chamada "separação pessoal de poderes ou funções" para que se evite o entrelaçamento pessoal de funções executivas e legislativas).

O aparente desafio político-institucional do Estado constitucional da pós-modernidade, considerada a polêmica que envolve a própria existência desta última, é fazer com que os três princípios acima elencados sejam observados de maneira sincrônica, evitando-se a hipertrofia de uma das funções em detrimento das demais.

A prática constitucional contemporânea mostra que a realidade política de um país com as dimensões e a diversidade cultural como o Brasil, cujo retrospecto de conturbadas rupturas institucionais têm revelado o valor da Constituição Federal de 1988, apresenta contextos que dificultam

22 CANOTILHO, J.J Gomes. Direito constitucional e teoria da constituição, Coimbra: Almedina. 7. ed., 2004. p. 250. 
o relacionamento entre os poderes instituídos, sobrecarregando um e esvaziando outro(s), como se pretenderá demonstrar adiante.

\section{A crise político-institucional brasileira e a sobrecarga do Poder Judiciário como instância decisória.}

Com o advento da redemocratização do Brasil, simbolizada ${ }^{24}$ com a promulgação da Constituição Federal de 1988, os paradigmas de compreensão e aplicação da doutrina da tripartição dos poderes, fornecidos tanto pelo Estado Liberal quanto pelos temperamentos sofridos com as transformações sociais decorrentes da ideologia do Estado do bem-estar social, demandaram e continuam a esperar por uma revisão.

Isso porque, como leciona José Afonso da Silva"25: "o Estado de Direito, quer como Estado Liberal de Direito quer como Estado Social de Direito, nem sempre caracteriza Estado Democrático.”, apontando que este último só se configura com a efetiva soberania popular, participação do povo na gestão dos negócios públicos e eficaz proteção dos ideais democráticos de defesa dos direitos fundamentais.

Como conseqüência, não se fazia mais pertinente a idéia de absoluta distinção entre as ordens jurídica e política, inclusive porque a primeira passava a disciplinar, de certa forma, a atividade da segunda, de modo que ambas serviriam para a formação do chamado 'espaço público'. A propósito da existência de uma conexão entre as ordens política e jurídica, esclarecedora é a lição de Nelson Saldanha, presente no seguinte trecho:

Nenhuma tentativa conceitual referente à distinção entre Política e Direito será satisfatória, se não considerar a ambas as coisas como formas de ordem. No caso da política, ordenação do poder e das relações básicas entre o poder e a comunidade; no caso do Direito, ordenação

$24 \quad \mathrm{O}$ termo aqui empregado remete às reflexões sobre a Constituição como símbolo da simbiose entre os sistemas político e jurídico, como proposto por Marcelo Neves: "A Constituição apresenta-se então como mecanismo de interpenetração e interferência entre dois sistemas sociais autopoiéticos, possibilitando-lhes, ao mesmo tempo, autonomia recíproca. Correspondentemente, concebida como instância interna do sistema jurídico (Direito constitucional), ela caracteriza-se como mecanismo de autonomia operacional do Direito. Nesse caso, tem-se em vista especificamente o processo de constitucionalização como distintivo do Estado de Direito moderno." In: NEVES, Marcelo. A Constitucionalização Simbólica. São Paulo: Acadêmica, 1994, pp. 129-130. 
das possibilidades de conduta e das alternativas referentes à aprovação e desaprovação de determinados atos por parte de determinadas instâncias. Em ambas as coisas há uma plano 'institucional', que lhes é essencial e que corresponde ao vínculo das estruturas com uma dimensão oficial (socialmente oficial), bem como ao próprio fato de serem ordenações globais. ${ }^{26}$

Houve, por assim dizer, uma 'politização' do Direito e porque não, uma 'juridicização' da Política, à medida que as normas constitucionais se convertem em instrumentos para a solução de impasses políticos, legitimando mandatos eletivos públicos e servindo de fundamento à concretização das aspirações dos cidadãos frente ao Estado.

A configuração desse Estado Democrático idealizado na Constituição de 1988, cuja confluência entre os sistemas político e jurídico resguardou uma série de direitos fundamentais, passou a exigir dos poderes instituídos postura diferente da adotada até então.

Não se trata aqui de afirmar, diante da previsão desse rol de direitos, que o poder constituinte tenha conferido maior responsabilidade a uma das funções do Estado, como fez o Min. Gilmar Ferreira Mendes ${ }^{27}$, do Supremo Tribunal Federal, assegurando que o país tinha formatado uma Constituição, cuja marca é a opção eminentemente judicialista, justificando o predomínio do Poder Judiciário, detentor da última, e porque não, da melhor palavra.

Sabe-se, por outro lado, que a forma de organização institucional, e mesmo procedimental, modelada antes da vigência da Constituição de 1988 não se apresentou suficientemente eficiente e célere para dar as respostas exigidas do Estado num contexto de transformações nos sistemas econômico, científico, cultural e das comunicações, resultantes da interação das diversas ordens nacionais, como expressão do fenômeno da globalização.

Isso explica, em parte, como o Poder Judiciário passou a ocupar espaços destinados ao Legislativo e ao Executivo, o que tem levado a doutrina a inclinar-se ao estudo das causas e condições da chamada judicialização da política.

Ultimamente, tem pertencido ao Poder Judiciário, por exemplo, a

26 SALDANHA, Nelson. Ordem e Hermenêutica. 2ed. rev. - Rio de Janeiro: Renovar, 2003, pp. 168-169.

27 Palestra proferida no VI Congresso Brasiliense de Direito Constitucional (Constituição e Governabilidade), realizado em 16 e 17 de outubro de 2003, sob o título "O STF, o controle de constitucionalidade e o equilíbrio de poderes". 
última palavra sobre a possibilidade ou não de verticalização de coligações para a disputa das eleições presidenciais ${ }^{28}$; a fidelização do parlamentar ao partido político pelo qual se elegeu ${ }^{29}$; a definição da chefia do Poder Executivo estadual em caso de vacância ${ }^{30}$; direito da minoria parlamentar em instaurar $\mathrm{CPI}^{31}$; deliberação sobre a possibilidade pesquisas científicas ${ }^{32}$; demarcação da área de reserva indígena ${ }^{33}$; além do debate sobre a organização da política pública de saúde ${ }^{34}$ e distribuição de medicamentos ${ }^{35}$, dentre outros temas que constituem, tipicamente, a agenda dos Poderes Legislativo e Executivo.

Os casos acima referenciados revelam a verdadeira sobrecarga do Poder Judiciário como instância decisória e são o exemplo de que a reivindicada releitura do princípio da separação de poderes tem suas razões, e não é por outro motivo que tanto estudiosos da Ciência Política quanto do Direito têm buscado oferecer alternativas para a solução dos impasses institucionais, com freqüência divulgados na mídia nacional.

O alerta necessário fazer nesse estado de coisas é que, longe de resolver os problemas ligados à solução de demandas sociais por direitos assegurados na Constituição, essa atrofia da função de julgar do Estado causa outros problemas, já que a instância do poder responsável pela análise daquelas demandas passa a pautar-se não na qualitativa efetivação de direitos, mas na célere e economicista resolução de casos, que se tornam infinitamente numerosos e repetitivos.

Outro grave problema verificado com o deslocamento desavisado da instância decisória no Estado Democrático tem caráter procedimental, ou seja, se no âmbito do processo legislativo ou administrativo a Constituição e o legislador definiram um caminho que julgavam ser legitimamente adequado

28 STF - ADI 3685/DF, Rel. Min(a). Ellen Gracie, julgamento em: 21.03.2006, publicação: DJ 10-08-2006 PP-00019 EMENT VOL-02241-02 PP-00193.

STF - ADI 3.999/DF e ADI 4.086/DF, Rel. Min. Joaquim Barbosa, julgamento em 12.11.2008.

31 STF - MS 26.441 -DF. Rel. Min. Celso de Mello, d.j. 25.04.2007. 23/08/2009.

35 Notícia - Folha de São Paulo de 09/01/2009 - Triplicam as ações judiciais para obter medicamentos. Levantamento do Ministério da Saúde revela que em 2008 foram gastos R \$ 52 milhões. 
para a discussão das demandas sociais postas à apreciação daqueles poderes, não parece lícito ao Poder Judiciário, que tem rito procedimental próprio, abarcar questões ínsitas à avaliação do legislador ou administrador.

Não se pode esquecer ainda a existência, como obstáculo à assunção das políticas públicas pelos tribunais, da discutida questão referente à legitimidade democrática dos membros da instância julgadora, como faz o professor Mauro Capelletti ${ }^{36}$, e até mesmo os problemas levantados por alguns doutrinadores quanto ao método de escolha dos juízes.

Examinando as condições e possibilidades de realização dos direitos no Estado Democrático sob o enfoque de dois referenciais teóricos, quais sejam o da teoria dos sistemas sociais de Niklas Luhmann e a teoria do discurso de Jurgen Habermas, o professor Marcelo Neves propõe que a existência de um "consenso procedimental" que sirva de foro para o "discenso conteudístico" deva servir como elemento legitimador do Estado Democrático, afirmando o seguinte:

...pode-se concluir que o Estado Democrático de Direito, pressupondo reciprocamente uma esfera pública pluralista, legitima-se enquanto é capaz de, no âmbito político-jurídico da sociedade supercomplexa da contemporaneidade, intermediar consenso procedimental e discenso conteudístico e, dessa maneira, viabilizar e promover o respeito recíproco às diferenças, assim como a autonomia das diversas esferas de comunicação. ${ }^{37}$

É certo que o incremento da atividade do Estado com a reformulação da atividade do Ministério Público; das garantias de vitaliciedade e inamovibilidade conferidas aos membros do Poder Judiciário, e o crescimento da influência da imprensa no meio social, agora com o espaço para a veiculação da livre manifestação de opinião, contribuíram para evidenciar aquela necessidade de dar nova compreensão ao princípio da divisão de poderes.

Aliada a esses fatores, a constatação do déficit de atuação atribuído às casas do Congresso Nacional, corpo da deliberação legislativa do país,

36 CAPELLETTI, Mauro. Juízes legisladores? Porto Alegre: Sérgio Antonio Fabris Editor, 1999.

37 NEVES, Marcelo. Entre Têmis e Leviatã: uma relação difícil: o Estado Democrático de Direito a partir e além de Luhmann e Habermas. $2^{\mathrm{a}}$ ed. - São Paulo: Martins Fontes, 2008, p. 156. 
cuja boa parte dos membros está constantemente envolvida em escândalos de corrupção e desvio ético, acabou por reforçar o significativo fosso entre a vontade popular (fonte da soberania do parlamento) e a inerte representatividade dos mandatários eleitos, elemento também contributivo para o mencionado deslocamento da decisão política para o Poder Judiciário.

Se nesse ambiente, oferecer um caminho adequado para a solução dos diversos impasses institucionais e a concentração demasiada de atribuições inerentes à decisão política no Poder Judiciário, não aparenta ser tarefa fácil, a releitura das lições de Aristóteles, sobre a virtude ética no exercício do poder político, parece ser mais do que recomendável aos agentes políticos acostumados a utilizar como privado o espaço que é público. 


\section{Referências Bibliográficas}

ARCAYA, Oscar Godoy. Antología Política de Montesquieu. Revista Estudios Públicos, otoño, 1996.

ARISTÓTELES. Política. $5^{\mathrm{a}}$ edição, trad. Pedro Constantin Tolens. São Paulo: Martin Claret, 2001.

BONAVIDES, Paulo. Do Estado Liberal ao Estado Social. 8 ed., São Paulo: Malheiros, 2007.

CANOTILHO, J.J Gomes. Direito Constitucional e Teoria da Constituição, Coimbra: Almedina. 7. ed., 2004.

CAPELLETTI, Mauro. Juízes Legisladores? Porto Alegre: Sérgio Antonio Fabris Editor, 1999.

KOSELLECK, Reinhart. Crítica e Crise: uma contribuição à patogênese do mundo burguês. Trad. de Luciana Villas-Boas Castelo-Branco. Rio de Janeiro: EDUERJ: Contraponto, 1999.

KOSELLECK, Reinhart. Futuro Passado: contribuição à semântica dos tempos históricos. Trad: Wilma Patrícia Maas, Carlos Alberto Pereira - Rio de Janeiro: Contraponto: Ed. PUC-Rio, 2006.

MATOS, Nelson Juliano Cardoso. O Dilema da Liberdade: alternativas republicanas à crise paradigmática no direito (o caso da judicialização da política no Brasil). Tese de Doutourado - Centro de Ciências Jurídicas / Faculdade de Direito do Recife, Universidade Federal de Pernambuco, Recife. 2007.

MONTESQUIEU, Charles Louis de. O Espírito das Leis. Trad. Cristina Muraschco. São Paulo: Martins Fontes, 1993.

MORAES, Alexandre de. Direitos Humanos Fundamentais. 2. ed. São Paulo: Atlas, v. 3, 1998.

Direito Constitucional. 21. ed. - São Paulo: Atlas, 2007. 
NEVES, Marcelo. A Constitucionalização Simbólica. São Paulo: Acadêmica, 1994.

. Entre Têmis e Leviatã: uma relação difícil: o Estado Democrático de Direito a partir e além de Luhmann e Habermas. 2a ed. - São Paulo: Martins Fontes, 2008.

SALDANHA, Nelson. Ordem e Hermenêutica. 2ed. rev. - Rio de Janeiro: Renovar, 2003.

SILVA, José Afonso da. Curso de Direito Constitucional Positivo. $26^{\mathrm{a}}$ ed. Malheiros Editores, 2006. 